\title{
Studies on HIV Resistance to Multiple Drug Therapy (Lamivudine, Zidovudine and Nevirapine) in Benin Metropolis, Nigeria
}

\author{
Ibeh IN*, Okungbowa, Ibeh NI and Isitua CC \\ *Department of Medical Lab. Sci. of Basic Med. Sci, College of Medical Sciences, University of Benin, Benin City, Nigeria
}

Received: 8 November, 2016; Accepted: 12 December, 2016 ; Published: 26 December, 2016

*Corresponding author: Ibeh IN, Department of Medical Lab. Sci. of Basic Med. Sci, College of Medical Sciences, University of Benin, Benin City, Nigeria, Tel: +2348023395367, +2349023372109; E-mail: ibehini@gmail.com

\begin{abstract}
Resistance to anti-retroviral drugs has long been recognized as a possible occurrence which may further complicate the management and control of microbial infections including the dreaded Human Immuno Deficiency Virus (HIV) infection. The present study evaluates cases of suspected unresponsiveness to Lamivudine, Zidovudine and Nevirapine (HAART) in Benin City Nigeria. Five adult males and females $(3 \mathrm{~m}, 2 \mathrm{f})$ between the ages of 35 - 50 years who had been on triple drug therapy (LZN) for a minimum of five years and were terminally ill in hospitals were recruited for this study. Venous blood (5.0mls) was collected from the subjects for analysis for viral antibodies, CD $4+\mathrm{T}$ cells and viral load determination. The subjects were then placed on $10.0 \mathrm{~g}$ of Manna and $20.0 \mathrm{mls}$ of Bioclean II daily and observed for 120 days. Venous blood samples were collected again at 30,60, 90 and 120 days after commencement of treatment for analysis. Skin rashes disappeared after 60days. There were increases in Body weight from $47.4(\mathrm{Kg})$ to $62.4 \mathrm{~kg}$, CD4 $4^{+} \mathrm{T}$ cells from 47.3 cells/ $\mu$ l to 327.8 and a reduction of viral load from $253,671.5$ copies/ml to 23, 240.3 copies.ml after 90 days. This finding suggests that the viruses carried by the individuals investigated in this study were not responding to Lamivudine + Zidevudine + Nevirapine. The implication is that resistance to HAART may be developing challenges to the management of HIV/AIDS in this community.
\end{abstract}

Keywords: Manna; Bioclean II; Lamivudine, Zidovudine; Nevirapine; HIV; AIDS; Nigerians

\section{Introduction}

Drug management of HIV/AIDS patients has centred on multi-drug therapy with the aim of fighting the virus from multidimensional fronts: to reduce viral resistance, quickly raise immune level of the patient to fight its own war in the body, decrease the viral load as quickly as it is possible, and increase the CD4 cells count in patients with reduced levels. Thus preventing the damage of immune system, make the patient live longer than they would have with the infection without drug therapy. The goal of HIV treatment is to reduce the amount of virus in a person's body and prevent destruction of the immune system. There is no doubt that since over thirty years of HIV/AIDS, the improvement of anti HIV drug production and therapeutic management of this ailment has superseded that of any other antiviral agent endeavour. For many years, the guideline recommends the use of two Nucleoside reverse transcriptase inhibitors or boosted protease inhibitors or the new integrase inhibitor. Other than these, there are other anti-HIV drugs in the groups of Fusion Inhibitors (FIs), Integrase Inhibitors (INIs) and Co-receptor Inhibitors (CRIs). Under HAART (Highly Active Antiretroviral Therapy) which commenced in the mid-90s, patients were made to take cocktails of Drugs. However, drug companies in an effort to increase compliance and adherence developed the currently five anti-HIV drug combinations: Combivir, Trizivir, Epzico/ Kivexza, Truvada and Atripla. These Drugs target HIV at different stages of life cycle. The combination therapy used in combating HIV infection has been based on the above mentioned strategy $[1,2]$.

The arsenal of drugs used in combating this disease has moved the prognosis of HIV from that of high morbidity and mortality to, for many at least, a chronic manageable but still complex disease, manifesting with drug toxicity, intolerable drug related side effects, development of drug resistance, loss of patient on treatment to follow up and the mere fact that some new HIV patients carry viruses resistant to the approved anti-HIV drugs. These developments suggest the need for the discovery of more intervention tools in the cycle of HIV/AIDS disease.

Bioclean II is a fermentation product of Nigerian plant roots and leaves that made its first appearance in public at a Research Exhibition Fair at Minna, Niger State and was further aired via Nigerian television Authority (NTA) through the "Voyage of Discovery" Programme anchored by African Independent Television (AIT). Bioclean II has been undergoing preliminary investigation to evaluate its effect on HIV/AIDS cases in Nigeria [3]. The present study aims at further evaluation of the activities of Bioclean II in relation to HAART with the addition of Manna. This is another product developed from roots and leaves with further fortification with trace elements [4].

\section{Research Questions}

Are there HIV resistant to HAART in Benin Metropolis? What 
is the prevalence if they do exist? What are the available options to deal with the situation?

\section{Materials and Methods}

\section{Sample Collection}

Candidates on HAART were recruited from Central Hospital, Stella Obasanjo Hospital, University of Benin Teaching Hospital and from private hospitals/private practitioners and volunteers who came on their own. Relevant documentations including informed consent forms and questionnaires were administered to all of them.

\section{Selection Criteria}

The selection criteria include, prior exposure to antiretroviral drugs ( Multiple therapy), for not less than five years, age bracket of 35 - 50 years and $\mathrm{CD}_{4}^{+} \mathrm{T}$ cells of less than $200 \times 10^{6}$ cells/ L, sero status - HIV 1 and 2 positive for the Antiretroviral Drug Wise Group (ARDW) and strict adherence to drug regimen.

\section{Exclusion Criteria}

Antiretroviral drug naïve (single, double or triple therapy exposure) multiple infection eg. TB, Syphilis, Age below 35.

\section{Methods}

The selected individuals were placed on $10 \mathrm{mls}$ of Bioclean II and 10.0g of Manna (Plate 1) twice daily. Blood samples were collected for analysis including time 0 (at the beginning of the treatment). The parameters evaluated were the viral load; $\mathrm{CD}_{4}{ }^{+} \mathrm{T}$ cells counts, viral antibody detection, body weights and physical appearance of each candidate.

\section{Viral antibody detection}

Briefly, $4.0 \mathrm{ml}$ of venous blood were collected from each subject into a sterile vacutainer tube containing ethylenediamine tetra acetic acid, $7.2 \mathrm{mg} / 4 \mathrm{ml}$ solution (BDF Plymouth, PL67BP; UK). The tubes were arranged in racks and allowed to stand at room temperature $\left(27 \pm 1.0^{\circ} \mathrm{C}\right)$ for 15 minutes. Using automatic pipettes, plasma was transferred from each tube into a pre-labelled plain specimen vial for the detection of antibodies to HIV 1 and 2 using HIV rapid testing kits.

Each sample was screened with Determine and Unigold kits run in parallel. Every sample that reacted with both kits was regarded as positive while a non-reactive one was regarded as negative. A reaction with only one of the two kits was regarded as discordant and stat pak was used as a tie breaker. A positive result with stat pak confirmed positivity of the sample. All test kits were evaluated for potency and shelf-life before use.

\section{$\mathrm{CD}_{4}{ }^{+} \mathrm{T}$ cells count}

Briefly, the reagents-PE antibody, partec buffer and count check beads stored at $4^{\circ} \mathrm{C}$ were brought out to attain room temperature $\left(27 \pm 1 \cdot 0^{\circ} \mathrm{C}\right)$. Using an automatic pipette (Eppendorf), $20 \mu \mathrm{l}$ of PE was dispensed into a partec tube. Then $20 \mu \mathrm{l}$ of well mixed sequestrated whole blood was added into the tube and shaken gently to mix the content thoroughly. The mixture was incubated in the dark at room temperature $27 \pm 1.0^{\circ} \mathrm{C}$ ) for
15 minutes, mixing at 5 minutes interval. Thereafter, $800 \mu \mathrm{l}$ of $\mathrm{CD}_{4}^{+}$ no lyse buffer was added to the tube and mixed gently. Then the tube was plugged to the counter (Flow cytometer; Partec Gmbh, Germany). During counting, it was ensured that the $\mathrm{CD}_{4}^{+}$bearing monocytes and noise were well separated and gated. The count check beads were run as control.

\section{Viral Load Determination}

This was done following the methods outlined by Ibeh et al [5]. Briefly, viral load was determined by the polymerase Chain Reaction method. Patient's blood and buffer were heated to a temperature of $95^{\circ} \mathrm{C}$ for the hydrogen bonds of the double helix of HIV DNA to be broken, resulting in single-stranded molecules to be used as temperate. This is the denaturation stage. This was followed by lowering the temperature to $50-56{ }^{\circ} \mathrm{C}$, to allow the primers to anneal to the appropriate single-stranded DNA template, forming short segments of double-stranded DNA where the polymerase attached to begin DNA synthesis. This was followed by the extension/elongation step at $72^{\circ} \mathrm{C}$ when the DNA polymerase $\left(\mathrm{T}_{\mathrm{aq}}\right)$ synthesized new DNA strands which were complementary to the HIV DNA template strands. By repeating the cycle of denaturation-annealing-syntheses, copies of the viral DNA were amplified with their $5^{\prime}$ and $3^{\prime}$ ends both set by the primers.

\section{Body Weight Measurement}

The body weights of individuals were taken using the standing weighing balance (the Big Boss, Hana).

\section{Statistics}

Data generated were analyzed statistically using SPSS package. The parameters determined include means, standard error, Analysis of Variance and locations of significant differences at the $95 \%$ and $99 \%$ confidence limits.

\section{Results}

The results in Table 1 show evidence of good response to treatment by the individuals investigated from 30days post exposure to Manna and Bioclean II. The body weights andCD4+ $\mathrm{T}$ cells had increased while the viral load started declining. Sixty days into treatment, skin rashes disappeared (Plates 2-4). This trend continued into 90days of treatment when significant increases in body weights and CD4+ $\mathrm{T}$ cells $(47.4-62.4 \mathrm{~kg}, 87.3-$ 327.8 cells $/ \mu \mathrm{l}$ respectively) were observed $(P<0.01)$; the viral load dropped significantly (253, 671.5 - 23,240.3 copies/ ml) within the same period $(P<0.01)$. These results are in agreement with the strategic expectations from an anti-retroviral agent's application.

\section{Discussion}

The present studies provide very interesting outcome and within a reasonable time (90days) (Table 1 ). The increases in body weight of the Individuals investigated suggest an improvement in the metabolic activities of the individuals investigated. This finding is in agreement with observations made in parallel studies elsewhere [3]. There was an improvement in the CD4+ 
T cells which suggests an enhancement of the immunity of the individuals investigated. This finding suggests that treatment improved the ability of the body to fight its own war against the

\begin{tabular}{|c|c|c|c|}
\hline $\mathrm{S} / \mathrm{N}$ & Time(In Days) & Parameters Tested & Mean Values \\
\hline 1 & 0 & $\begin{array}{l}\text { Body weight }(\mathrm{Kg}) \\
\text { Viral Antibodies } \\
\mathrm{CD} 4^{+} \mathrm{T} \text { cells }(\text { cells } / \mu \mathrm{l}) \\
\text { Viral loads (copies } / \mathrm{ml} \text { ) }\end{array}$ & $\begin{array}{l}47.4 \\
+ \\
87.3 \\
253,671.5\end{array}$ \\
\hline 2 & 30 days & $\begin{array}{l}\text { Body weight }(\mathrm{Kg}) \\
\text { Viral Antibodies } \\
\mathrm{CD} 4^{+} \mathrm{T} \text { cells }(\text { cells } / \mu \mathrm{l}) \\
\text { Viral loads (copies/ ml) }\end{array}$ & $\begin{array}{l}56.8 \\
+ \\
126.8 \\
212,074.3\end{array}$ \\
\hline 3 & 60 days & $\begin{array}{l}\text { Bbody weight }(\mathrm{Kg}) \\
\text { Viral Antibodies } \\
\mathrm{CD} 4^{+} \mathrm{T} \text { cells }(\text { cells } / \mu \mathrm{l}) \\
\text { Viral loads (copies/ ml) }\end{array}$ & $\begin{array}{l}60.4 \\
+ \\
246.4 \\
87,214.7\end{array}$ \\
\hline 4 & 90 days & $\begin{array}{l}\text { Body weight }(\mathrm{Kg}) \\
\text { Viral Antibodies } \\
\mathrm{CD} 4^{+} \mathrm{T} \text { cells }(\text { cells } / \mu \mathrm{l}) \\
\text { Viral loads (copies/ ml) }\end{array}$ & $\begin{array}{l}62.4 \\
+ \\
327.8 \\
23,240.3\end{array}$ \\
\hline
\end{tabular}

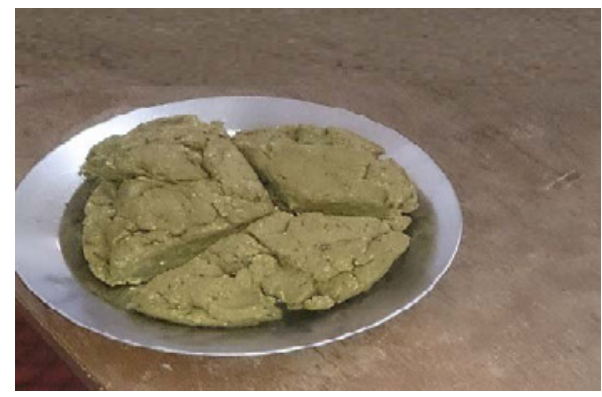

Figure 1: Manna

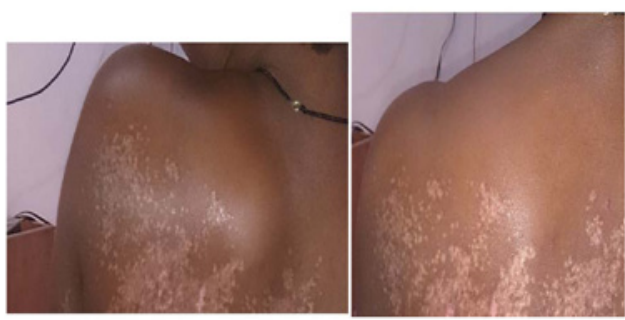

Figure 2,3: represent skin rashes on the individuals investigated

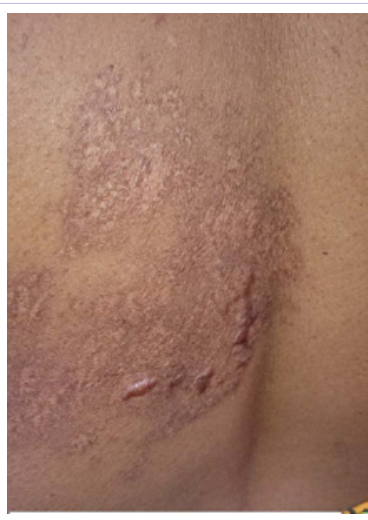

Figure 4: Skin rashes of an individual investigated

retroviruses, since the $\mathrm{CD}^{+} \mathrm{T}$ cells are important determinants of outcome of the disease $[1,2]$.

The viral load of the individuals investigated in this study dropped significantly $(P<0.01)$, suggesting that treatment generated some virucidal activities. This finding is in agreement with earlier reports $[3,5]$. The implication is that Manna and Bioclean II possess anti-retroviral activities that are distinct from that of Lamivudine, Zidovudine and Nevirapine. Since the Individuals investigated had been on the latter anti-retrovirals without good results, in fact they were released from hospitals as hopeless cases, it provides putative evidence that virus resistance to HAART do exist in our community.

There is need for further studies to determine the prevalence of HAART failure due to virus resistance in our community and evaluate Manna + Bioclean II and any other agents for their potential as alternative intervention tools in HIV/AIDS diseases.

\section{References}

1. UNAIDS Intensifying HIV presentation: a UNAIDS Policy Position Paper. 2005.

2. UNAIDS Report on the global AIDS epidemics. 2010.

3. Ibeh IN, Akanu N, Mkpa AM, Isitua CC, Ogefere H O. Evaluation of the Anti-Human Immunodeficiency Virus (HIV) Properties of DXL (Decoction X-Liquid-Bioclean Ii). J Clin Toxicol. 2013;S12-004. doi: 104172/2161-0495.S12-004.

4. Ibeh IN. Wholesome Foods and the intervening Variables between Government and People. The $157^{\text {th }}$ Inaugural Lecture series of University of Benin, Benin City, Nigeria. 2015:80.

5. Ibeh IN, Okungbowa MA, Ibeh NI, Adejumo BI. Comparative studies on the effects of Zidovudine + Nevirapine + Lamivudine and Bioclean II on female HIV/AIDS cases in Nigeria. JAMPS. 2016;9(3):1-7. doi:10.9734/2015/16569. 